\title{
Relation between Substitution of Threonine for Isoleucine at B2 Adrenergic Receptor on Bronchial Asthma in Children
}

\author{
Samir Zamzam ${ }^{1}$, Khalid Mohamed Salah ${ }^{1}$, Rania Mohammed Mohammed Amer ${ }^{2}$, Rana Ahmed Waheed*1 \\ Departments of ${ }^{1}$ Pediatrics, ${ }^{2}$ Microbiology and Immunolgy, Faculty of Medicine - Zagazig University, Egypt \\ *Corresponding Author: Rana Ahmed Waheed, Mobile: (+20)01024683929, E-mail mosad8rashed@gmail.com
}

\begin{abstract}
Introduction: Pediatric asthma is a complex disorder involving immunologic, genetic, environmental and other factors. Objective: To evaluate the role of substitution of threonine for isoleucine at codon 164 on bronchial asthma susceptibility, severity and response to short- and long- term acting $\beta_{2}$-adrenergic receptor agonists in children. Patients and Methods: This study was a prospective case control study, which was done in Pediatric Department of Zagazig University Hospital from Pulmonology Clinic in the period from February 2016 to February 2018. 100 children were included, 50 of them had asthma with bronchodilator and their ages ranged from 5 to 12 years (25 males and 25 females) with the mean age of $6.8 \pm 2.5$ years. In addition, 50 healthy age and sex matched worked as control children. All studied groups were subjected to full history taking, clinical examination, pulmonary function tests, total serum $\operatorname{IgE}$ and identification of adrenergic $\beta_{2}$ receptor $\left(\mathrm{ADR} \beta_{2}\right)$ substitution of threonine for isoleucine at codon 164 polymorphism. Results: In this study, there was a significant association between homozygous isoleucine and increase incidence of asthma, this mean that the gene gives harmful effect when it is in a homozygous form. However, there was no statistically significant difference between asthma severity and gene polymorphism (CC, CT and TT). Conclusion: In the present study ADR $\beta$ Thr164Ile polymorphism is reported as an important variant at salbutamol refractoriness in sever asthmatics. In addition, the polymorphism form is susceptible variant to develop asthma risk.
\end{abstract}

Keywords: Threonine for Isoleucine, Adrenergic Receptor and bronchial, asthma, ADR $\beta_{2}$.

\section{INTRODUCTION}

Asthma is a complex inflammatory disorder that has multifactorial inheritance mediated by a variety of environmental triggers. According to WHO, it affects about 300 million people worldwide and approximately 250000 patients die from asthma annually (1). Several factors influence development of asthma including gene (that predispose individual to atopy and airway hyper-responsiveness), obesity, sex and environmental causes like house dust mites, animal fur and fungi. There is also viral infections, tobacco smoke, air pollution and eating habits. Additionally some immunological characteristics, such as immune system maturation and the number of exposure to infectious agents at first year of life. These factors affect the risk of developing asthma ${ }^{(2)}$. A number of single nucleotide polymorphism have been reported in ADR $\beta_{2}$. Four of these results in amino acid substitutions at amino acids16, 27, 34 and164, whereas the silent mutations are located at amino acids 84, 175, 351 and 43. Inhaled $\beta_{2}$ agonists have been established as first line in treatment of asthma as it has excellent bronchodilator effect, low side effects and wide range therapeutic range ${ }^{(3)}$.

$\beta 2$ agonist form an effective and well tolerated bronchodilator in patients with asthma ${ }^{(4,5)}$. In studies using site-directed mutagenesis and recombinant expression, the amino acid substitution in the receptor alter function of receptor leading to pathology in body. The replacement of threonine with isoleucine at 164th position in $\beta_{2}$ adrenergic receptor leads to decrease of ligand-receptor interactions and decline of coupling of $\beta_{2} \mathrm{AR}$ to adenylyl cyclase are often observed.

The aim of this work was to evaluate the role of substitution of threonine for isoleucine at codon 164

on bronchial asthma susceptibility, severity and response to short- and long-term acting $\beta_{2}$ adrenergic receptor agonists in children.

\section{PATIENT AND METHODS}

This study was a prospective case control study, which was done in Pediatric Department of Zagazig University Hospital from Pulmonology Clinic in the period from Feb 2016 to Feb 2018. It was done on 100 children, 50 of them had asthma with bronchodilator and their ages ranged from 5 to 12 years $(25$ males and 25 females) with the mean age of $6.8 \pm 2.5$ years and 50 healthy age and sex matched control children.

Inclusion criteria: Children having asthma according to Global Initiative for Asthma Management and Prevention, 2016. Ensure that the child could understand and perform the pulmonary function maneuvers efficiently.

Exclusion criteria: Other allergic disorders. Children with any chronic disease other than asthma that may affect pulmonary function. Children with restrictive pattern in spirometry.

Ethical and Patients' approval: Written Informed consent was taken from the patients' parents to participate in the study. Approval for performing the study was obtained from Pediatrics, Microbiology 
and Immunology Departments, Zagazig University Hospitals after taking Institutional Review Board (IRB) approval. The work has been carried out in accordance with the code of ethics of the world medical association (Decleration of Helsinki) for studies involving humans.

\section{Methods:}

Our patients were subjected to full history taking and clinical examination, pulmonary function tests, total serum $\mathrm{IgE}$ and identification of $\mathrm{ADR} \beta_{2}$ substitution of threonine for isoleucine at codon 164 polymorphism. Cases of intermittent asthma treated with selective beta 2 agonist as salbutamol in inhalation forms as $100 \mathrm{mcg} /$ metered inhalation, the daily dose is one puff of the metered aerosol, 3 times daily.

Anthropometric measurements:

Weight, height, body mass index (BMI). For the diagnosis of overweight, if the BMI is at least the $85^{\text {th }}$ percentile but less than the $95 \%$ for the age and sex:

$$
\mathrm{BMI}=\text { Weight }(\mathrm{Kg}) / \text { Height }\left(\mathrm{m}^{2}\right)
$$

Assessment of asthma severity according to the Guidelines of Global Initiative for Asthma Management and Prevention (2016):

Classification of asthma severity into intermittent, mild persistent, moderate persistent and severe persistent.

Performance of spirometry: Forced vital capacity (FVC), forced expiratory volume in first second (FEV1) and FEV1/FVC were measured by a spirometer (D-97024 Hochberg, Germany).
Every subject underwent three assessments and the highest value of them was recorded.

\section{Laboratory investigations:}

Assessment of total serum IgE. Identification of ADR $\beta 2$ Thr164 Ile polymorphism using ARMS- PCR method. Serum IgE level (1-2 ml of venous blood was collected on gel containing serum collecting tubes, incubated in room temperature and centrifuged at 2000x g samples were stored at $-20^{\circ} \mathrm{C}$ ).

\section{Statistical Analysis}

The data were coded, entered and processed in computer using SPSS (version 18). The results were represented in tabular and diagrammatic forms then interpreted. Mean, standard deviation, range, frequency, and percentage were use as descriptive statistics. The following test was done: Chi-Square test was used to test the association variables for categorical data. Student's t-test was used to assess the statistical significance of the difference between two population means in a study involving independent samples. Student's paired t-test was used to assess the statistical significance of the difference between two population means in a study involving paired samples. ANOVA (F test) for normal quantitative variables, to compare between more than two groups and Post Hoc test (LSD) for pairwise comparisons. $\mathrm{r} \rightarrow$ Pearson's Product correlation coefficient to evaluate the linear association between 2 quantitative variables (one is the independent var. $\mathrm{X}$ and the other is the dependent var., $\mathrm{Y})$. Value of " $\mathrm{r}$ " ranges from -1 to 1 . $\mathrm{P}$ value was considered significant as the following: $\mathrm{P}>0.05$ : Nonsignificant, $\mathrm{P} \leq 0.05$ : Significant.

\section{RESULTS}

Table (1): Demographic characteristics of the studied groups

\begin{tabular}{|c|c|c|c|c|c|c|}
\hline & & & $\begin{array}{l}\text { Patients } \\
(\text { No.=50) }\end{array}$ & $\begin{array}{l}\text { Control } \\
\text { (No.=50) }\end{array}$ & t. test & P. value \\
\hline Age (vears) & Mez & & $8.10 \pm 2.52$ & $8.44 \pm 2.40$ & 0.689 & 0.492 \\
\hline & Male & No. & 25 & 25 & & \\
\hline Som & Male & $\%$ & $50.0 \%$ & $50.0 \%$ & $\mathbf{X}^{2}$ & 1000 \\
\hline Sex & Fomole & No. & 25 & 25 & 0.000 & 1.000 \\
\hline & Female & $\%$ & $50.0 \%$ & $50.0 \%$ & & \\
\hline
\end{tabular}

No significant differences were found between asthmatic children and control as regard age and sex (Table 1)

Table (2): Distribution of common risk factors among patients

\begin{tabular}{|l|c|c|c|c|}
\hline \multicolumn{1}{|c|}{ Risk factors } & \multicolumn{2}{c|}{ Positive. } & \multicolumn{2}{c|}{ Negative. } \\
\cline { 2 - 5 } & No. & $\mathbf{\%}$ & No. & $\mathbf{\%}$ \\
\hline Smoke exposure. & 18 & 36 & 32 & 64 \\
\hline Urinary tract infection (URTI) & 34 & 68 & 16 & 32 \\
\hline Exercise-induced asthma. & 25 & 50 & 25 & 50 \\
\hline Family history of asthma or atopy & 26 & 52 & 24 & 48 \\
\hline
\end{tabular}

This table showed the distribution of common risk factors among the studied groups. URTI showed the highest incidence of risk factors $(68 \%)$, followed by exercise-induced asthma and positive family history which exerted the same frequency among patients (52\%), while smoke exposure was the least frequently occurring risk factor among patients (36\%) as shown in table (2). 
Table (3): Comparison between grades of asthma severity regarding Total IgE level

\begin{tabular}{|c|c|l|l|l|l|l|l|}
\hline \multicolumn{2}{|c|}{} & Mild asthma & Moderate asthma & Severe asthma & F & P. value & \\
\hline $\begin{array}{c}\text { Total } \\
\text { IgE } \\
\text { level }\end{array}$ & $\begin{array}{c}\text { Mean } \pm \text { SD } \\
\text { (IU/mI) }\end{array}$ & $215.22 \pm 53.55$ & $719.72 \pm 87.42$ & $635.18 \pm 12.80$ & 4.894 & 0.012 & $\begin{array}{c}\text { P1 }=0.005 \\
\text { P2 }=0.762 \\
\text { P3 }=0.04\end{array}$ \\
\hline
\end{tabular}

P1--- $\rightarrow$ between mild asthma and moderate asthma

P2-- $\rightarrow$ between moderate asthma and severe asthma

P3--- $\rightarrow$ between mild asthma and severe asthma

There was a statistically significant difference between mild asthma and moderate asthma regarding total $\operatorname{IgE}$ level $(\mathrm{P}$. value $=0.005)$. There was no statistically significant difference between moderate asthma and severe asthma regarding total IgE level $(\mathrm{P}$. value $=0.762)$. There was statistically significant difference between mild asthma and severe asthma regarding total IgE level $(P$. value $=0.04)$ as shown in table (3).

Table (4): Comparison between patients and control regarding gene polymorphism

\begin{tabular}{|c|c|c|c|c|c|c|}
\hline & & & ents & Control & $\mathbf{X}^{2}$ & P. value \\
\hline \multirow{2}{*}{ Homozygous THREONINE } & \multirow{2}{*}{$\begin{array}{c}\text { Thr/Thr } \\
\text { Homozygous }\end{array}$} & No. & 8 & 8 & \multirow{2}{*}{.0} & \multirow{2}{*}{1} \\
\hline & & $\%$ & $16.0 \%$ & $16.0 \%$ & & \\
\hline \multirow{2}{*}{$\begin{array}{l}\text { Heterozygous } \\
\text { THR/ISOLEUCINE }\end{array}$} & \multirow{2}{*}{$\begin{array}{c}\text { Thr/Ile } \\
\text { Heterozygous }\end{array}$} & No. & 18 & 28 & \multirow{2}{*}{4.026} & \multirow{2}{*}{.045} \\
\hline & & $\%$ & $36.0 \%$ & $56.0 \%$ & & \\
\hline \multirow{2}{*}{ Homozygous ISOLEUCINE } & \multirow{2}{*}{ Ile/Ile Homozygous } & No. & 24 & 14 & \multirow{2}{*}{4.244} & \multirow{2}{*}{.039} \\
\hline & & $\%$ & $48.0 \%$ & $28.0 \%$ & & \\
\hline
\end{tabular}

There was no statistically significant difference in the prevalence of homozygous (Thr/Thr) genotype between patients and controls. However, the prevalence of heterozygous ( $\mathrm{Thr} / \mathrm{Ile}$ ) was significantly higher in the control group and the prevalence of homozygous (Ile/Ile) was significantly higher in the patients group (Table 4).

Table (5): Description of asthma severity among patients regarding gene polymorphism

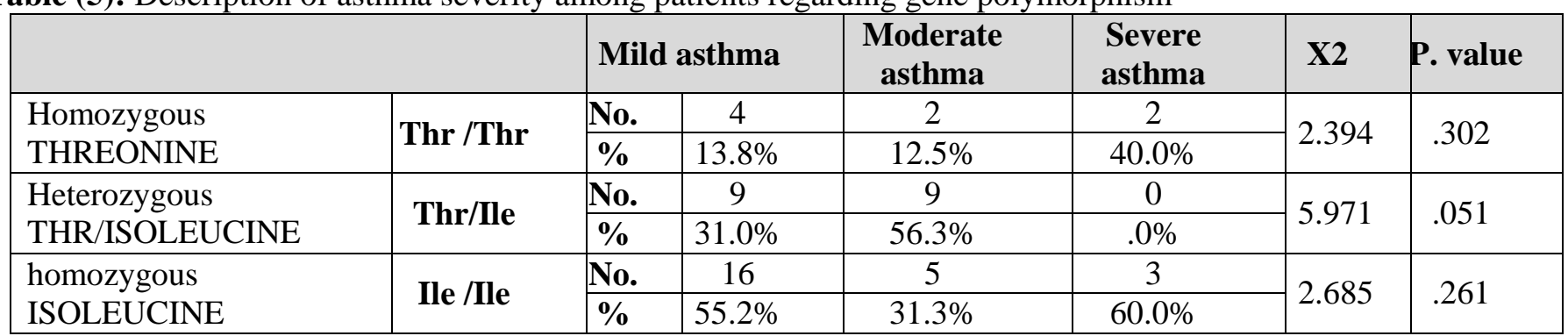

There was no statistically significant difference between asthma severities regarding the gene polymorphism (Table 5).

Table (6): Comparison between pre-nebulized $\beta_{2}$ agonist FEV1 $\%$ and post-nebulized $\beta_{2}$ agonist FEV1\% among asthmatic children regarding gene polymorphism

\begin{tabular}{|l|c|c|c|c|c|}
\hline & $\begin{array}{c}\text { Pre nebulized B2 } \\
\text { agonist FEV1 \% } \\
\text { Mean +SD }\end{array}$ & $\begin{array}{c}\text { post nebulized B2 } \\
\text { agonist FEV1\% } \\
\text { Mean +SD }\end{array}$ & $\begin{array}{l}\text { Paired } \\
\text { sample } \\
\text { t. test }\end{array}$ & $\begin{array}{c}\text { P. } \\
\text { value }\end{array}$ & $\begin{array}{c}\text { Mean } \\
\text { difference } \\
\text { \% }\end{array}$ \\
\hline $\begin{array}{l}\text { Homozygous } \\
\text { THREONINE }\end{array}$ & $71.11 \pm 12.66$ & $87.68 \pm 5.40$ & $-5.635-$ & 0.001 & 16.57 \\
\hline $\begin{array}{l}\text { Heterozygous } \\
\text { THRONINE/ } \\
\text { ISOLEUCINE }\end{array}$ & $77.3 \pm 9.54$ & $91.86 \pm 11.68$ & $-7.825-$ & 0.001 & 14.56 \\
\hline $\begin{array}{l}\text { Homozygous } \\
\text { ISOLEUCINE }\end{array}$ & $79.45 \pm 13.06$ & $93.17 \pm 9.06$ & $-8.766-$ & 0.00 & 13.71 \\
\hline
\end{tabular}

Table (6) showed that FEV1 values before and after nebulized $\beta_{2}$ agonist and the percentage of difference. Patients having homozygous threonine were significantly responsive to $\beta_{2}$ agonist $(16.57 \%)$, followed by heterozygous Thr/Ile (14.56\%), while patients having homozygous isoleucine respond to $\beta_{2}$ agonist (13.71\%) as shown in table (6).

\section{DISCUSSION}

This study showed that, there was no statistical significant difference between cases and controls regarding age and sex. This agrees with Hoshino et al. (6) who done his study on Forty-two healthy controls and 20 patients with asthma. He found that there were no significant differences in age and gender were observed between the two groups.

This study showed that, positive family history was found in $52 \%$ of patients while no family history was found in $48 \%$ of patients. This agrees with Hassane et $\boldsymbol{a l} .{ }^{(7)}$ who made case-control study that 
included 43 Egyptian outpatients with asthma. 21 apparently matched healthy children were included as controls. He found increase in asthma occurrence among children with family history. This result is in accordance with Magdy et al. ${ }^{(8)}$ who stated that positive family history of asthma was a risk factor for asthma where family history of asthma is common.

In our study, smoke exposure was found to be a risk factor among patients (36\%). This means that exposure to tobacco smoke is one of the most consistent risk factors in the development and exacerbation of asthma. This result is in accordance with Vargas $\boldsymbol{e t}$ al. (9) who found that environmental tobacco smoke exposure has been associated with the increased use of the Emergency Department for acute asthma care.

This study showed that there was a statistically significant increase in total $\mathrm{IgE}$ level among moderate asthma than mild asthma (P. value $=0.005)$. There was no statistically significant difference between moderate asthma and severe asthma regarding total $\mathrm{IgE}$ level (P. value $=0.762$ ). There was a statistically significant increase in total IgE level among severe asthma than mild asthma $(\mathrm{P}$. value $=0.04)$. There was statistically significant positive correlation between total IgE level and eosinophilic count. This agrees with Inoue et al. ${ }^{(10)}$ where twenty-eight children with asthma (BA) and 27 children without asthma (as control group) aged 6-16 years were included. The asthmatic group also had a significantly higher eosinophil count $[298.5 \pm 571.1$ vs $87.9 \pm 263.0 / \mu \mathrm{l}(\mathrm{p}<0.001)]$ and total $\mathrm{IgE}$ level $[328.6 \pm$ 1201.8 vs $20.3 \pm 282.0 \mathrm{IU} / \mathrm{ml}(\mathrm{p}<0.001)]$.

Regarding risk factors distribution among asthmatic patients in the current study, URT infection was considered the highest incident risk factor in the studied group $(68 \%)$, followed by exercise-induced asthma and positive family history, which represented the same percentage (52\%) then smoke exposure (36\%). Subbarao et al. (11) confirms our results regarding distribution of risk factors of asthma.

In our study, there was a significant association between homozygous isoleucine and increase incidence of asthma, this mean that the gene gives harmful effect when it is in a homozygous form. However, there was no statistically significant difference between asthma severity and gene polymorphism (CC, CT and TT). This finding disagrees with Bandaru et al. ${ }^{(12)}$ who found no association between the genetic polymorphism in that locus and increased incidence of bronchial asthma.

Our study showed different FEV1 values before and after nebulized $\beta_{2}$ agonist. Patients who are homozygous threonine are significantly responsive to $\beta_{2}$ agonist $(16.5 \%)$, followed by heterozygous threonine/ isoleucine (14.56\%), while patients having homozygous isoleucine response to $\beta_{2}$ agonist (13.7\%). This finding agrees with Maxwell et al. (13) who found the substitution of $\mathrm{T}$ allele in place of $\mathrm{C}$ allele at 491 positions in $\mathrm{ADR} \beta_{2}$ leads to mutation (Thr164lle) in the receptor, which displays decreased agonist binding and depressed coupling of $\beta_{2} \mathrm{AR}$ to adenylyl cyclase, so there is significant association of the polymorphism and salbutamol refractoriness.

Polymorphism at Ile 164 receptor was documented to be a reason for suboptimal response to salbutamol.

\section{CONCLUSION}

In the present study, ADR $\beta$ Thr164Ile polymorphism reported as an important variant at salbutamol refractoriness in sever asthmatics. In addition, the polymorphism form susceptible variant to develop asthma risk.

\section{RECOMMENDATIONS}

To combine more than one locus of $A D R \beta_{2}$ in the same study, in order to be able to understand haplotype-genotype interaction. To conduct further pharmacogenomics studies on $\beta_{2}$ adrenergic receptor on Egyptian asthmatic children to reach a more genotypeguided practice and to compare more than one drug category in relation to SNPs on large sample size.

\section{REFERENCES}

1. Masoli M, Fabian D, Holt S et al. (2004): The global burden of asthma: executive summary of the GINA Dissemination Committee report. Allergy, 59 (5): 469-78.

2. Anandan C, Nurmatov U, Van Schayck O et al. (2010): Is the prevalence of asthma declining? Systematic review of epidemiological studies. Allergy, 65 (2): 152-67.

3. Woods BD, Sladen RN (2009): Perioperative considerations for the patient with asthma and bronchospasm. Br J Anaesth., 103: 57-65.

4. O'Byrne P, Bisgaard H, Godard $P$ et al. (2005): Budesonide/formoterol combination therapy as both maintenance and reliever medication in asthma. Am J Respir Crit Care Med., 171 (2): 129-36.

5. Lemanske R, Sorkness $\mathbf{C}$, Mauger $\mathbf{E}$ et al. (2001): Inhaled corticosteroid reduction and elimination in patients with persistent asthma receiving salmeterol: a randomized controlled trial. JAMA., 85 (20): 2594-603.

6. Hoshino M, Ohtawa J, Akitsu K (2016): Effect of treatment with inhaled corticosteroid on serum periostin levels in asthma. Respirology, 21 (2): 297-303.

7. Hassane F, Khatab A, Saliem S et al. (2015): Low magnesium concentration in erythrocytes of children with acute asthma. Menoufia Medical Journal, 28 (2): 477-80.

8. Zedan M, Settin A, Farag M et al. (2009): Prevalence of bronchial asthma among Egyptian schoolchildren. Egypt J Bronchol,, 3 (2): 124-30.

9. Vargas P, Brenner B, Clark S et al. (2007): Exposure to environmental tobacco smoke among children presenting to the emergency department with acute asthma: a multicenter study. Pediatr Pulmonol., 42 (7): 646-55.

10. Inoue T, Akashi K, Watanabe $M$ et al. (2016): Periostin as a biomarker for the diagnosis of pediatric asthma. Pediatr Allergy Immunol., 27 (5): 521-6.

11. Subbarao P, Mandhane $P$, Sears $M$ (2009): Asthma: epidemiology, etiology and risk factors. Cmaj., 181 (9): 18190.

12. Bandaru S, Tarigopula P, Akka J et al. (2016): Association of Beta 2 adrenergic receptor (Thr164Ile) polymorphism with Salbutamol refractoriness in severe asthmatics from Indian population. Gene, 592 (1): 15-22.

13. Maxwell T, Ameyaw M, Pritchard S et al. (2005): Beta-2 adrenergic receptor genotypes and haplotypes in different ethnic groups. Int J Mol Med., 16 (4): 573-80. 